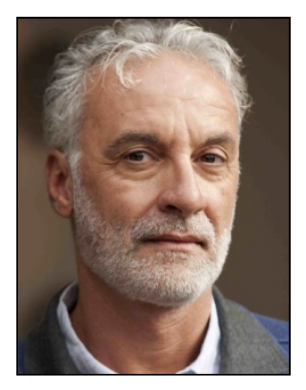

\title{
COMMENTARY
}

\section{Looking at Sierra Leone's Ebola epidemic through an agrarian lens}

Rami Zurayk

American University of Beirut

Citation: Zurayk, R. (2014). Looking at Sierra Leone's Ebola epidemic through an agrarian lens

[Commentary]. Journal of Agriculture, Food Systems, and Community Development, 5(1), 15-20.

http://dx.doi.org/10.5304/jafscd.2014.051.005

Copyright (C) 2014 by New Leaf Associates, Inc.

W hen the residents of the small town of Fort Kent in rural Maine expressed their concerns about Sierra Leone's Ebola epidemic arriving "on their doorstep" (Freyer, 2014), they may have not known that they were right to realize that Sierra Leone is actually far closer to the United States than may be immediately obvious. The West African country, which is about the size of the state of Maine, is home to a population of six million, among whom many are descended from the 1,200 freed enslaved people who were brought back from the U.S. in 1791. The freed slaves had been

Rami Zurayk is professor at the Faculty of Agricultural and Food Sciences at the American University of Beirut, Lebanon. His research addresses issues at the nexus of food, landscapes, and livelihoods. He is an active member of Lebanese civil society and a founding member of the Arab Network for Food Sovereignty. His book Food, Farming, and Freedom: Sowing the Arab Spring was published by Just World Books in 2011. He can be contacted at ramizurayk@gmail.com. returned to the same spot of the African coast from which millions of slaves had been shipped to the U.S. to work in the rice and sugar cane plantations.

The history of Sierra Leone is one of dispossession, enslavement, exploitation, and thievery at the hand of local, colonial, and imperial powers. These hardships have contributed to the enrichment of many, including Hollywood magnates and actors who dug into the country's 1991-2002 civil war, fueled by the illegal sale of the country's diamonds, for inspiration. The award-winning 2006 movie Blood Diamond, starring Leonardo DiCaprio, grossed over US $\$ 170$ million, of which the people of Sierra Leone never saw a single cent.

For this is Sierra Leone's predicament: its people do not benefit from its riches. For instance, while natural resources abound, especially fertile lands, diamonds, and tropical forests, the country is plagued by land grabs, blood diamonds, and conflict timber (McCoy, 2014). Sierra Leone is one of 
the poorest countries in the world, with a Human Development Index ranking in 2013 of 183 out of 187 (United Nations Development Programme [UNDP], 2014).

\section{Rural Sierra Leone: Poverty, Food Insecurity, and Land Grabs}

Like its population, poverty in Sierra Leone is mainly rural. Data from the World Food Programme (WFP) shows that up to 70 percent of the population live below the national poverty line of US\$2 per day (WFP, 2011, p. 31). Food insecurity is rife: 45 percent of people are food insecure (WFP, 2011, p. 9). Even though 95 percent of the population grow food crops (WFP, 2008, p. X), 63 percent of the household income is spent on food (WFP, 2011 p. 34). However, farming is the exclusive source of livelihood for just 15 percent of producers (WFP, 2008, p. 57), and only 5.5 percent of rice cultivators can feed their families from their own production for the whole year (WFP, 2011, p. 38). Livelihood diversification strategies are essentially based on natural resources: oil palm extraction, fishing, animal husbandry, or charcoal-making. Coping strategies in times of crises are essentially borrowing food and money (WFP, 2008, p. 53)

Although yields are very low (often below 1 metric ton per hectare or 0.45 U.S. tons per acre), Sierra Leone's small farmers produced about 80 percent of the country's rice needs in 2010 (WFP, 2011, p. 19). The rest is imported from volatile international markets. Improving access to agricultural inputs and introducing better farming practices would greatly contribute to enhancing the sustainability of production, and would have positive impacts on food security and poverty alleviation. A relatively straightforward agrarian development program aiming to bolster small farm productivity needs to be put in place with the clear goals of improving access to resources and bridging the yield gap using agroecological approaches. The issue of land tenure and fair access to resources will need to be given careful consideration, as tenure is predominantly communal and under the control of local chiefs. This system is unfavorable to vulnerable groups who cannot easily gain access to land, and to women who cannot inherit land (Larbi, 2012).
Instead of an agrarian revolution aimed at improving the sustainability of small farmers, rural Sierra Leone is experiencing a different kind of agricultural restructuring. According to a recent report commissioned by international organizations (Baxter, 2013), up to one-fifth of the country's farmland has been leased since 2009 to industrial agriculture investors, most often for the production of bioethanol from palm oil and sugar cane. International investors co-opt local chiefs to serve the projects at the expense of their traditional duties, which include fair allocation of land to cultivators. Money becomes the main currency of social power, to the great disadvantage of the poor and the disenfranchised.

These investments have resulted in turning scores of farmers into farmworkers earning wages of US $\$ 2-$ US $\$ 3$ per day, dangerously close to the poverty line. It is sadly ironic that the descendants of the freed slaves from the sugarcane fields of America are now held in quasibondage as wage laborers in sugarcane farms and factories in their own countries. Examples of agricultural investment projects include 44,000 ha (109,000 acres) of longterm land leases to the Addax Corporation in the district of Bombali, and 42,000 ha (104,000 acres) to the same corporation in Port Loko district, where there is widespread discontent about the deals (Baxter, 2013). Port Loko is also the site of a controversial project by the Portuguals Quifel Group, whose work started in Brazil but, attracted by lower land prices, was moved to Sierra Leone (Environmental Justice Atlas, 2014). In total, 231,326 ha (40 percent of the total area of the districts) in seven of 11 chiefdoms of Port Loko have been leased (Baxter, 2013, p. 14). It is worth noting here that the independent WFP report reported that over 70 percent of households in Port Loko are food insecure (WFP, 2011 p. 10). A full environmental, social, and economic impact assessment and cost-benefit analysis, including a wealth of quantitative data about agriculture in Sierra Leone, can be found in the extensive report by Baxter (2013).

\section{An Epidemic Anchored in Rurality}

It is against this agrarian backdrop that the rural origin and spread of the current Ebola epidemic 
must be examined. This is especially important as reports at the time of writing (November 2014) indicate that the virus may be spreading " 9 times faster" than two months ago in rural Sierra Leone while it is subsiding in neighboring Liberia (Al Jazeera, 2014).

The rural origins of the current epidemic can be traced with relative certainty to a first case that may have involved bat-child infection in Guinea. Its toll, however, has been heaviest in rural Sierra Leone. Experts agree that the mechanism and modalities underlying the spread in rural areas are still unknown. For David Heymann, professor of infectious disease epidemiology at the London School of Hygiene and Tropical Medicine, speaking to the UK's Guardian (Krysiak, 2014), the inability to stop the epidemic in rural areas is baffling, as "there is better community organisation...traditional systems which help people better understand the cause of the disease and how to prevent spread" (para. 7). He dismisses the possibility that this may be due solely to an ailing health system, since previous epidemics in Zaire and the Democratic Republic of the Congo were controlled in spite of the existing poor health systems. Richards et al. (2014), one of the few research teams with direct access to present-time field data, called the spread in rural areas "the least understood part of the epidemic" (para. 1). They report in an article in the PLOS Neglected Tropical Diseases on the interaction between the pathways of transmission of the disease and social networking in rural communities, with particular focus on the relationships between marriage, funerals, and land tenure. Funeral rites, including the washing of corpses, are practiced in order to mark the "end" of marriage and address the complex issue of land rights. The authors also look at the role of migration and (food) markets in the transmission of the disease. They conclude that risk reduction may require rural people to adapt their behavior regarding funeral rites to the Ebola crisis, something they have observed to be currently happening. However, they recommend improved access to health-care facilities, transportation to hospitals and triage centers, and health education about the modes of transmission of the disease.

Most of the emerging literature on the 2014
Ebola outbreak has focused on the epidemiological and medical determinants of the spread of the disease. A few, such as the insightful article by Richards et al. (2014), have addressed the socio-cultural determinants of the crisis. Even fewer have sought to unravel in any depth the ecological and livelihood linkages (Bausch \& Schwarz, 2014; McCoy, 2014). Bausch and Schwarz (2014) underscore the importance of the sociopolitical landscape in the emergence and spread of Ebola. Driven by need, the poor move into the forest and tap natural resources to diversify vulnerable livelihoods, thus increasing risks of exposure. This "dive into the forest" for income supplementation is indeed the main livelihood diversification of the vulnerable in Sierra Leone (WFP, 2008, p. 57).

My own rudimentary spatial analysis of the current outbreak confirms the marked linkages between the socio-politico-economic landscape and the spread of the epidemic in rural Sierra Leone. As of November 7, and according to data released by the Government of Sierra Leone (Government of Sierra Leone, 2014), the cumulative confirmed cases of Ebola had reached 4,234. Fiftythree percent of these cases were in 4 of the 14 districts of the country: these are Port Loko (565) and Bombali (631) (both proximal districts in the North), and Kailahun (555) and Kenema (490) (both proximal districts in the South). Overlaying this information with the available data on poverty, food security, and economic activity shows that these districts are also home to 45 percent of the nation's farmers and include 45 percent of its farmland. While geographically, ethnically, and ecologically distinct, the affected districts are also among the poorest of the country (WFP, 2011 p. 32). Kenema is the center of both the (blood) diamond trade and the mining industry. As shown above, Bombali and Port Loko are zones of expansion of overseas agricultural investments for bioethanol production. Kailahun is the coffee and cocoa growing zone and was also a stronghold for Revolutionary United Front (RUF) rebels during the civil war, when forests were decimated to fund the conflict.

\section{Beyond the Biomedical Response}

There is little doubt left that poverty and food insecurity are closely associated with the spread of 
Ebola. When people spend over two-thirds of their incomes on food, and 3 percent on education and 3 percent on soap (WFP, 2011 p. 34), it does not take a genius to figure that out. However, poverty is merely an indicator, a number, a statistic. What is more important than listing poverty figures and associating them with biomedical circumstances is to develop an in-depth understanding of why people are poor in Sierra Leone. The mechanisms underlying the dispossession, the local accumulation, as well as the flight of capital outside of this resource-rich but money-poor country must be understood, exposed, and dismantled. The latter poses serious questions regarding the role of the global financial policeman, the U.S., which largely controls the flow of money in the global economy and is able to pursue, sue, and embargo entire nations, such as Iran and South Korea, by tracing money all the way into individual accounts in commercial banks tens of thousands of miles away from the U.S. mainland. There is also a pressing need to evaluate the impact of decades of international aid to Sierra Leone. Donor countries currently cover up to 20 percent of the cost of Sierra Leone's health sector (McCoy, 2014) but as the current epidemic shows, there is not much to show for it. The role of the swarm of micro-NGOs in the health and other sectors such as rural development needs particular scrutiny. As the Ebola crisis has shown, these do not have a sustainable impact. Kenema district has its very own WWOOF program (see http://www.wwoofsl.org/preview.php). Kailahun, with its cocoa and coffee plantations, is an area predisposed to organic farming and fair trade. The Ebola epidemic has dismantled the fragile architecture of development aid and alternative trade. A report from the FairMatch Support organization dated October 20, 2014, reveals that work was frozen on May 30, 2014, and that 17,000 cocoa and coffee growers are now out of the certification and trade program as they could not be audited, while 20 local staff were sent home on leaves without pay (Huurdeman, 2014).

The Ebola crisis has elicited responses from across the globe. Nearly every international medical NGO and UN organization have intervened in some way. The U.S. and the UK have formed a minicoalition and have sent troops (Mpoke Bigg and Fofana, 2014). China is building a hospital in Liberia. Even Cuba has sent a team that has been lauded for its people-oriented, sustainable development approach (Sifferlin, 2014). The United Nations is calling for investments in the health system, the latest estimates being US $\$ 1$ billion (UNMEER, 2014). The International Monetary Fund (IMF) has already approved US $\$ 130$ million in new credit for Sierra Leone, Guinea, and Liberia (IMF, 2014). There is a race between pharmaceutical corporations for the development of a vaccine (Economist, November 1, 2014).

Two not unrelated issues emerge here: one is the question of whether it is at all possible to build a (health) system that will operate durably within a larger sociopolitical system that does not. This seems to negate the most basic laws of systems. The issue of the possibility of constructing a standalone, effective, and functional health system in Sierra Leone where plunder, pillage, and economic laissez-faire dominate the scene needs deeper consideration before starting to accumulate debt.

The second issue relates to why are we seeing such willingness on behalf of the international community to participate in the battle against Ebola. After all, we live in a world where 3.1 million children die every year from a fully preventable death by malnutrition (WFP, 2014). One is tempted by the easy answer: because Western/ financial capital's interests are threatened. It is true that the diamond trade has receded during this period, but there is so much reserve in De Beers vaults that this setback will only contribute to increasing profits due to temporary scarcity. I am also not convinced of the argument that involves the potential exposure of the entire world due to globalization, as experts agree that Ebola is relatively easy to contain where proper structures exist (Walsh, 2014).

There may be a different explanation for the rush to fight Ebola, inspired by Slovene philosopher and cultural theorist Slavoj Zizek. In Sophie Fiennes' 2012 movie A Pervert's Guide to Ideology, Zizek offers an interesting analysis of the classic Hollywood movie Jaws. For Zizek, Jaws symbolizes the lumped fears of U.S. society. For the working class, it is the rich, blood-sucking capitalists. For the average anticommunist, it represents Castro's 
Cuba. The obliteration of the shark in the movie symbolizes the annihilation of all these fears, providing psychological solace without actually having to directly address any of the fear-triggering issues. I contend that Ebola is today used as the materialization of the ailments of Africa, and that the vast mobilization will achieve an epic victory in halting the epidemic that will substitute for addressing any of the real political and economic problems remaining in Africa. This is akin to the relief felt by spectators when, after a heroic battle involving an impressive array of weaponry, Roy Scheider blasts the shark in the movie's apocalyptic final scene. This, of course, did not prevent Hollywood from producing Jaws 2 and Jaws 3 a few years later...

\section{References}

Al Jazeera. (2014, November 2). Ebola cases 'surge' in rural Sierra Leone. Al Jazeera News. Retrieved from http://www.aljazeera.com/news/africa/2014/11/e bola-cases-surge-rural-sierra-leone-2014112221854 603455.html

Bausch, D. G., \& Schwarz, L. (2014). Outbreak of Ebola virus disease in Guinea: Where ecology meets economy. PLOS Neglected Tropical Diseases, 8(7), e3056. http://dx.doi.org/10.1371/journal.pntd.0003056

Baxter, J. (2013). Who is benefitting? The social and economic impact of three large-scale land investments in Sierra Leone: A cost benefit analysis. Freetown, Sierra Leone: Action for Large-scale Land Acquisition Transparency (ALLAT). Retrieved from http://www.christianaid. org.uk/images/who-is-benefitting-Sierra-Leonereport.pdf

Economist, The. (2014, November 1). Vaccine-makers and Ebola: Giving it a shot. Retrieved from http://www.economist.com/news/business/21629 399-drugmakers-bet-vaccines-will-help-fightagainst-ebola-giving-it-shot

Environmental Justice Atlas. (2014). Quifel Agribusiness agrofuels or foodcrops projects in Port Loko, Sierra Leone. Retrieved November 6, 2014, from http://ejatlas.org/conflict/quifel-agribusinessagrofuels-or-foodcrop-projects-in-port-loko-sierraleone

Freyer, F. (2014, October 31). The specter of Ebola arrives on the doorstep of rural Maine. The Boston
Globe. Retrieved from http://www.bostonglobe. com/metro/2014/10/30/the-specter-ebola-arrivesdoorstep-rural-maine/3AFQuK1qf DIJ9zITH sujOO/story.html

Government of Sierra Leone. (2014). Ebola outbreak updates-November 7, 2014. Retrieved from http://reliefweb.int/sites/reliefweb.int/files/ resources/Ebola-Update-November-7-2014.pdf

Huurdeman, K. (2014). Ebola report from Sierra Leone. Retrieved from the FairMatch Support website: http://www.fairmatchsupport.nl/en/ebola-reportfrom-sierra-leone-2

International Monetary Fund (IMF). (2014). IMF approves $\$ 130$ million for countries worst hit by Ebola. Retrieved from http://www.imf.org/external/ $\mathrm{pubs} / \mathrm{ft} / \mathrm{survey} / \mathrm{so} / 2014 / \mathrm{new} 092614 \mathrm{a} . \mathrm{htm}$

Krysiak, E. (Producer). (2014, November 4). What does the Ebola crisis reveal about the state of global health? podcast transcript. Retrieved from The Guardian Global Development website: http://www. theguardian.com/global-development/2014/nov/ 04/ebola-crisis-global-health-podcast-transcript

Larbi, A. (2012). Country pasture/forage resources profiles: Sierra Leone. Retrieved November 6, 2014, from http://www.fao.org/ag/agp/AGPC/doc/ Counprof/Sierraleone/Sierraleone.htm

McCoy, D. (2014, November 3). The social, political and ecological pathologies of the Ebola crisis cannot be ignored [Web log post]. Retrieved from http://blogs.bmj.com/bmj/2014/11/03/davidmccoy-the-social-political-and-ecologicalpathologies-of-the-ebola-crisis-cannot-be-ignored/ Mpoke Bigg, M., \&Fofana, U. (2014, October 8). U.N. Liberia medic catches Ebola; Sierra Leone burial teams end strike. Reuters [U.S. Edition]. Retrieved from http://www.reuters.com/article/2014/10/ 08/us-health-ebola-liberia-un-idUSKCNOHXOY 520141008

Richards, P., Amara, J., Ferme, M. C., Kamara, P., Mokuwa, E., Sheriff, A. I., Suluku, R., \& Voors, M. (In press). Social pathways for Ebola virus disease in rural Sierra Leone, and some implications for containment. PLOS Neglected Tropical Diseases. Retrieved from http://blogs.plos.org/speakingof medicine/2014/10/31/social-pathways-ebolavirus-disease-rural-sierra-leone-implicationscontainment/ 
Sifferlin, A. (2014, November). Why Cuba is so good at fighting Ebola. Time. Retrieved from http://time.com/3556670/ebola-cuba/

United Nations Development Programme [UNDP]. (2014). Human Development Report 2014: Sierra Leone. Retrieved from http://hdr.undp.org/sites/all/ themes/hdr_theme/country-notes/SLE.pdf

United Nations Mission for Ebola Emergency Response [UNMEER]. (2014, October 17). External situation report. Retrieved from http://www.un.org/ebola response/pdf/Situation Report-Ebola170ct14.pdf
Walsh, B. (2014, October 21). Why Ebola isn't really a threat to the U.S. Time. Retrieved from http://time.com/3525385/ebola-threat-us-cdc/

World Food Programme [WFP]. (2008). Sierra Leone: bousehold food security survey in rural areas. Retrieved from http://home.wfp.org/stellent/groups/ public/documents/ena/wfp216299.pdf

WFP. (2011). The state of food security and nutrition in Sierra Leone 2011. Retrieved from http://documents. wfp.org/stellent/groups/public/documents/ena/ wfp250158.pdf

WFP. (2014). Hunger statistics. Retrieved November 8, 2014, from http://www.wfp.org/hunger/stats 